\title{
Distributional patterns of the South American species of Hyalella (Amphipoda: Hyalellidae)
}

\section{Patrones de distribución de especies sudamericanas de Hyalella (Amphipoda: Hyalellidae)}

\author{
Patricio De los Ríos-Escalante ${ }^{1,2}$, Juan J. Morrone ${ }^{3}$ \& Reinaldo Rivera ${ }^{1,4}$ \\ ${ }^{1}$ Universidad Católica de Temuco, Facultad de Recursos Naturales, Escuela de Ciencias Ambientales, Laboratorio de Ecología \\ Aplicada y Biodiversidad; Casilla 15-D, Temuco, Chile. patorios@msn.com and prios@uct.cl. \\ ${ }^{2}$ Núcleo de Estudios Ambientales UCTemuco \\ ${ }^{3}$ Museo de Zoología "Alfonso L. Herrera", Departamento de Biología Evolutiva, Facultad de Ciencias, Universidad Nacional \\ Autónoma de México (UNAM), Apartado Postal 70-399, 04510 Mexico, D.F., Mexico. juanmorrone2001@yahoo.com.mx. \\ ${ }^{4}$ Departamento de Zoología, Universidad de Concepción, Casilla 160-C, Concepción, Chile.
}

\begin{abstract}
Distributional patterns of the South American species of the freshwater amphipod genus Hyalella were analysed using a panbiogeographic approach. Five generalized tracks were found: (1) northern Andes to Lake Titicaca (H. dielaii, H. meinerti, H. dybowskii, H.jelskii, H. lubominsky, and H. pauperocavae; (2) lake Titicaca (H. armata, H. cuprea, H. latinamus, H. lucifugax, $H$. montforti, $H$. neveulemairei, H. robusta, H. tiwanaku, H. simplex simplex, and $H$. solida); (3) central Andes (H. fossamancinii and H. kochi); (4) Pampas (H. bonariensis, H. caeca, H. castroi, H. longispina, H. montenegrinae, H. pampeana, H. pernix, H. pseudoazteca, and H. warmingii); and (5) Subantarctic (H. patagonica H. costera, H. curvispina, $H$. chiloensis, $H$. falklandensis, $H$. franciscae, $H$. neonoma, $H$. patagonica, and $H$. simplex). One node was found at lake Titicaca (intersection of generalized tracks 1, 2, and 3).
\end{abstract}

KeYwords: Chile, Hyalella South America, biogeography

\section{RESUMEN}

Se estudió el patrón de distribución de especies Sudamericanas del género de anfípodo de agua dulce Hyalella mediante una aproximación panbiogeográfica. Se encontraron cinco trazos (1) Norte de los Andes al Lago Titicaca (H. dielaii, H. meinerti, H. dybowskii, H.jelskii, H. lubominsky, y H. pauperocavae; (2) Lago Titicaca (H. armata, H. cuprea, H. latinamus, H. lucifugax, H. montforti, H. neveulemairei, H. robusta, H. tiwanaku, H. simplex simplex, y H. solida); (3) Andes centrales (H. fossamancinii y H. kochi); (4) Pampas (H. bonariensis, H. caeca, H. castroi, H. longispina, H. montenegrinae, H. pampeana, H. pernix, H. pseudoazteca, y H. warmingii); y b (5) Subantártico (H. araucana, H. costera, H. curvispina, $H$. chiloensis, $H$. falklandensis, $H$. franciscae, $H$. neonoma, $H$. patagonica, y $H$. simplex). Se encontró un nodo en el lago Titicaca que correspondió a la intersección de los trazos 1;2 y 3.

Palabras clave: Chile, Hyalella Sudamérica, biogeografía

\section{INTRODUCTION}

Freshwater amphipods inhabit superficial and underground waters. They have different trophic roles: herbivores, carnivores, detritivores or omnivores (Witt and Hebert 2000; Väinöla et al. 2008). In South America, amphipods are represented by species inhabiting subterranean (Bogidellidae) and superficial (Hyalellidae) waters (Väinöla et al. 2008). Hyalellidae are represented in the Americas by the genus Hyalella, which has been recently studied from a taxonomic perspective (Witt and Hebert 2000; Witt et al. 2003; González and Wattling 2002a-c, 2003a-c; González 2003; González et al. 2006), and is possibly found in New Zealand (Pugh et al. 2002).

Recent studies on Chilean species of Hyalella indicate that they inhabit subsaline inland waters, such as streams and shallow ponds in northern Chile (González 2003; De los Ríos et al. 2010), coastal inland waters (González 2003), and oligotrophic inland waters of Patagonia between 38- 
$51^{\circ} \mathrm{S}$ (González 2003; De los Ríos et al. 2007; De los Ríos and Roa 2010). Similar studies have investigated Central Argentina and Patagonia (Lopretto 1982, 1983a, b; Miserendino 2001; Jergentz et al. 2004; Miserendino et al. 2008; Zilli et al. 2008).

Integrative biogeographic studies of the species of Hyalella have not yet been conducted. Here we undertake a preliminary track analysis of the South American species of this genus to improve current understanding of their patterns of geographical distribution.

\section{MATERIAL AND METHODS}

Distributional data for this study were obtained from the literature (Lopretto 1982, 1983a, b; Pereira, 1985, 1989, 2004 Pereira et al. 1985, 1989; Stock and Plavoet 1991; Bond-Buckup and Araujo 1998; Casset et al. 2001; González and Coleman 2002; González and Wattling 2002a-c, 2003ad; Carrera and Günkel 2003; González 2003; Jergentz et al. 2004; Pereira 2004; Coleman \& González, 2006; Galan \& Herrera, 2006; González et al. 2006; Da Silva and BondBuckup 2008; Dos Santos et al. 2008; Dutra et al. 2008; Zilli et al. 2008; Rauque and Semenas 2009; Spaccesi \& Rodríguez. 2009; De los Ríos et al. 2007, 2010; De los Ríos and Roa 2010; Cardoso et al., 2011; Bastos-Pereira \& De Padua-Bueno, 2012). It was not cosidered the species names $H$. curvispina cangallensis, $H$. aff. curvispina, H. thomseni, H. sapropelica and H. lalage (Brehm-Lunz, 1928, 1935; Gonzalez \& Wattling, 2003c; González et al., 2006)

Coordinates of localities were obtained from the literature or calculated on maps and rounded to minutes. Within each country, localities are ordered roughly in a south-north direction. For details on the localities of each species see Appendix.

The panbiogeographic approach involves plotting distributions of different taxa on maps and joining their separate localities with lines called individual tracks. These tracks represent the geographical coordinates of species or higher taxa. Operationally, they consist of lines drawn on a map connecting the localities at which the taxa occur according to their geographical proximity. When different individual tracks are superimposed, the resulting summary lines are considered generalized tracks, which are interpreted as indicating the pre-existence of ancestral biotas that subsequently became fragmented by tectonic and/or climatic change. If two or more generalized tracks intersect in a given area, they determine a node, which indicates that different ancestral biotic and geological fragments interrelate in space and time as a consequence of terrain collision, docking or suturing. This node thus constitutes a composite area. For further details about panbiogeographic methods, see Morrone (2004, 2006, 2009).

\section{RESULTS}

Individual tracks and localities of the species analyzed are represented in figures 1-9. In northern South America, $H$. anophthalma, H. azteca and H. inermis has been reported from Venezuela (Fig. 1a) and $H$. paramoensis from northern Colombia (Fig. 1b). Hyalella quindioensis has been reported in inland mountain waters of the Colombian Andes (Fig. 2a). In the northern Andean inland waters, H. simplex cangallensis (Fig. 1c), H. pauperocavae (Fig. 2b), H. lubomirskii (Fig. 3a), H. dybowskii (Fig. 2c), and H. meinerti (Fig. 3b) have been reported. In coastal zones of Lake Titicaca (Peru and Bolivia), 17 species have been reported: $H$. echinus, $H$. crawfordi, $H$. gauthieri, $H$. longipalma, $H$. neveulemairei, $H$. cuprea, $H$. nefrens, $H$. armata, H. lucifugax, H. montforti, H. tiwanaku, H. longipes, $H$. latimanus, $H$. robusta, $H$. longispina, $H$. solida, and $H$. jelskii (Fig. 4a). Hyalella fossamancinii has been reported from inland waters of the Andes Argentina and northern Chile (Fig. 4b). Hyalella kochi occurs in Argentinean and Chilean mountain inland waters (Fig. 5a). Several species have been reported near the Atlantic coast: H. gracilicornis (Fig. 4c), H. warmingi (Fig. 5b), H. pernix (Fig. 5c), $H$. spelaea, H. longistila (Fig. 6a), H. caeca (Fig. 6b), and $H$. dielaiii (Fig. 4d). The following species have been reported from southern Brazil: $H$. carstica (Fig. 2e), H. longistila (Fig. 2f), H. pseudoazteca (Fig. 5d), H. montenegrinae (Fig. 6c), H. castroi (Fig. 7a), and H. pleoacuta (Fig. 7c). Two species are restricted to streams from Buenos Aires province, Argentina: H. bonariensis (Fig. 6d) and H. pampeana (Fig. 7b). The species $H$. costera has been reported from coastal wetlands, streams, and shallow ponds from northern Chilean Patagonia to northern Chile, in the Antofagasta region (Fig. 7d). Hyalella chiloensis has been reported from Central Patagonia, coastal lakes in Chiloé Island, and Concepción in central Chile (Fig. 6e). Hyalella falklandensis (Fig. 7e) and $H$. neonoma (Fig. 5e) have been reported from the Falkland Islands (Islas Malvinas). In Patagonia, including nearby islands, $H$. patagonica has been reported (Fig. 1e). In Argentina, H. curvispina has been reported from southern, central and northern Argentinean Patagonia in large and deep lakes and in Buenos Aires province; it has also been reported from the Falkland Islands, Uruguay, southern Brazil specifically in coastal inland waters, and from Peru (Fig. 8a). Hyalella rionegrina has been reported from one locality in Chubut province, in Argentinean Patagonia (Fig. 2d). A species restricted to Chile is $H$. simplex, is known from southern Chilean Patagonia, specifically from coastal inland waters of the Strait of Magellan strait and from a high-mountain shallow lake in northern Chilean Patagonia 


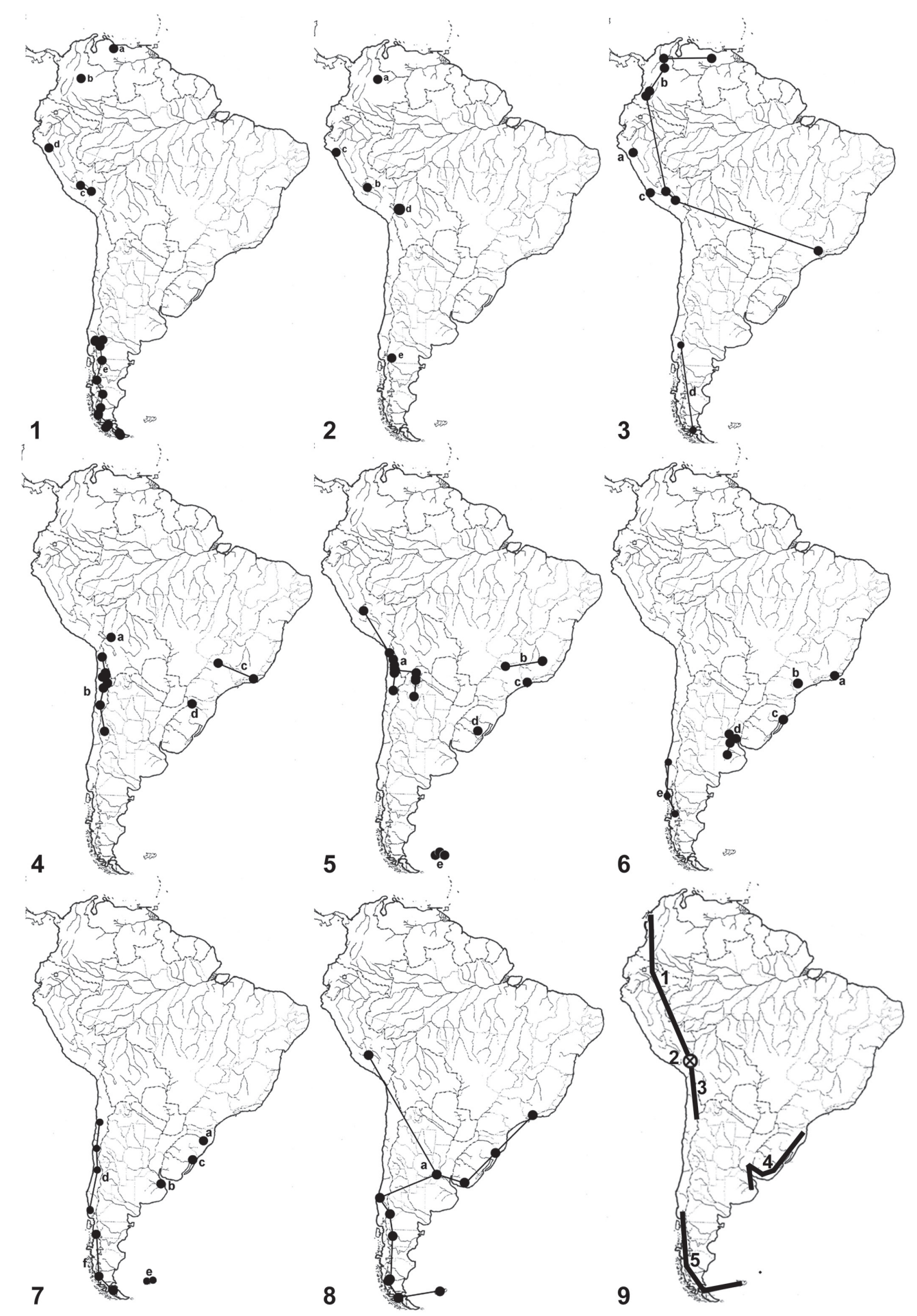

FIGURAs 1-8. Individual tracks: 1, Hyalella anophtala, H. azteca, H. inermis (a), H. paramoensis (b), H. simplex cangallensis (c), Hyalella patagonica (d); 2, H. quindioensis (a), H. pauperocavae (b), H. dybowskii (c), H. rionegrina (d); 3, H. lubomirskii (a), H. meinerti (b), H. jelskii (c), H. simplex (d); 4, H. longipalma, H. neveulemairei, Hyalella cuprea, H. nefrens, H. armata, H. lucifugax, H. montforti, H. tiwanaku, H. longipes, H. latimanus, H. robusta, H. longispina, and H. solida (a), H. fossamanchini (b), H. gracilicornis (c), H. dielaiii (d); H. carstica (e); 5, H. kochi (a), H. warmingi (b), H. pernix (c), H. pseudoazteca (d), H. neonoma (e); H. longistila (6); 6, H. longistila (a), H. caeca (b), H. montenegrinae (c), H. bonariensis (d), H. chiloensis (e); 7, H. castroi (a), H. pampeana (b), H. pleoacuta (c), H. costera (d), H. falklandensis (e), H. franciscae (f); 8, H. curvispina (a). Fig. 9. Generalized tracks and nodes; 1, northern Andes generalized track; 2, lake Titicaca generalized track and node; 3, central Andes generalized track; 4, Pampas generalized track; 5, Subantarctic generalized track. 
(Fig. 3d). Hyalella franciscae has been reported from lakes of Torres del Paine National Park, in the Magellan region (Fig. 7f).

Based on the overlap of the different individual tracks, we identified five generalized tracks (Fig. 9):

(1) Northern Andes. Inland waters of Venezuela and Peru between $10^{\circ} \mathrm{N}-15^{\circ} \mathrm{S}$. The species assigned to this track are H. anophtalma, H. inermis, H. quindioensis, H. paramoensis, H. meinerti, H. dybowskii, H.jelskii, H. lubominsky, and $H$. pauperocavae.

(2) Lake Titicaca. The species assigned to this track are $H$. armata, $H$. crawfordi, $H$. cuprea, $H$. echinus, $H$. gauthieri $H$. latinamus, $H$. lucifugax, $H$. montforti, $H$. neveulemailei, H. robusta, $H$. tiwanaku, $H$. simplex simplex and $H$. solida.

(3) Central Andes. Inland waters from central Argentina $\left(31^{\circ} \mathrm{S}\right)$ to northern Chile $\left(18-26^{\circ} \mathrm{S}\right)$. The species assigned to this track are $H$. fossamancinii and $H$. kochi.

(4) Pampas. Inland waters close to the Atlantic coast from Buenos Aires province $\left(35^{\circ} \mathrm{S}\right)$ in central Argentina to Uruguay and southern Brazil $\left(19^{\circ} \mathrm{S}\right)$. The species assigned to this track are $H$. bonaeriensis, $H$. caeca, H. carstica, $H$. castroi, $H$. dielaii, $H$. longistila, $H$. montenegrinae, $H$. pampeana, $H$. pernix, $H$. pseudoazteca, and $H$. warmingii.

(5) Subantarctic. Andean inland waters of Argentina and Chile between $39-51^{\circ} \mathrm{S}$, southern Patagonian plains between 51-53 $3^{\circ}$, Tierra del Fuego, and the Falkland Islands. Species assigned to this track are $H$. curvispina, $H$. chiloensis, $H$. falklandensis, $H$. franciscae, H. neonoma, H. patagonica, and H. simplex.

One node (Fig. 9) was found where generalized tracks 1, 2, and 3 intersect, at lake Titicaca.

\section{DISCUSSION}

The generalized tracks identified are similar to those described by Menu-Marque et al. (2000), who applied this procedure to the copepod genus Boeckella. That study identified a generalized track in southern Patagonia, the Atlantic coast of Argentina, the Andean mountains of northern Argentina and Chile, and the Andean regions of Bolivia, Colombia and Ecuador. Nevertheless, the nodes reported in the present study differ from those identified by Menu-Marque et al. (2000). Species of Hyalella are also known from Mexico and Central America, Bousfield (1996) supported it, and suggested the presence of Austrohyalella and Mesohyalella genus in South America. Nevertheless, the recent literature mentioned the presence of Hyalella genus for all American continent (Väinöla et al., 2008; Witt \& Hebert 2000; Wit et al., 2006)

The absence of nodes in southern Patagonia agrees with analyses for Subantarctic islands (Pugh et al. 2002) and southern South America (Dos Santos et al. 2008), about similarities between continental Subantarctic species. Our results contrast with those from calanoid copepods (MenuMarque et al. 2000) and fishes of the genus Galaxias (Cussac et al. 2004), that are known from southern Patagonia, New Zealand and adjacent islands, a different situation was reported for species of Hyalella that are widespread in South North America (Witt \& Hebert, 2000; Witt et al. 2003). The results of geographical distribution of Hyalella genus are similar in comparison to freshwater crabs of Aegla genus that is located in central and southern Argentina and Chile, and east South America, specifically Brazil and Uruguay (Pérez-Lozada et al., 2002, 2004, 2009). Nevertheless, species reports for practically all South American inland waters are rather scarce, so future analyses may modify these results, specifically between $18-8^{\circ} \mathrm{N}$, the Titicaca basin, and eastern South America.

\section{ACKNOWLEDGEMENTS}

The present study was funded by projects DGI-CDA-200701 and MECESUP Project UCT 0804. The authors recognize the contributions of Luciano Parra to the preparation of the present manuscript.

\section{REFERENCES}

Andres, H.G. 1988. Hyalella paramoensis sp. n. aus de Paramo de Chisaca (Anden) (Crustacea: Amphipoda: Talitroidea). Mittheilungen der Hamburgischen Zoologischen Museum und Institut 85: 103-109.

Bastos-Pereira, R., \& De Padua-Bueno, A.A. 2012. New species and new report of Hyalella S.I. 1874 (Crustacea: Amphipoda: Dogielinotidae) from Minas Gerais state, Southeastern Brazil. Zootaxa 3350: 58-68.

Bond-Buckup, G. \& Araujo, P. 1998. Hyalella montenegrinae sp. n., um Amphipoda de águas continentais do sul do Brasil (Custacea, Peracarida, Hyalellidae). Nauplius (Río Grande) 6: 53-59.

Bond-Buckup, G., Jara, C.G., Pérez-Lozada, M., Buckup, L., \& Crandall, K.A. 2008. Global diversity of crabs (Aeglidae: Anomura: Decapoda) in freshwater. Hydrobiologia 595: 267-273.

Bousfield, A. 1996. A contribution to the reclassification of Neotropical freshwater hyalellid amphipods (Crustacea: Gammaridea, Talitroidea. Bolletino del Museo Civico di Storia Naturale de Verona 20: 175-224.

BreHM, V. 1938. La fauna microscópica del Lago Petén, Guatemala. 
Anales de la Escuela Nacional de Ciencias Biológicas, IPN 1 (2): 173-204.

Brehm-LunZ, V.1928. Hydrobiologishe untersuchungen aus Uruguay. Archiv für Hydrobiologie 19: 719-722.

Brehm-Lunz, V. 1925. Zoologishe ergebnisse der von Prof. F. Klute nach Nord Patagonien unernommenen forschungreise. 1. Die entomostraken. Archiv für Hydrobiologie 16: 302324.

Cardoso, G.M., De Padua Bueno, A.A., \& Ferreira, R. 2011. A new troglobiotic species of Hyalella (Crustacea, Amphipoda, Dogielinotidae) from Southeastern Brazil. Nauplius 19: 7-26.

Carrera, P., \& Gunkel, G. 2003. Ecology of a high Andean stream, Rio Itambi, Otavalo, Ecuador. Limnologica 33(1): 29-43.

Casset, M.A., Momo, F.R., \& Giorgi, A.D.N. 2001. Dinámica poblacional de dos especies de anfípodos y su relación con la vegetación acuática en un microambiente de la cuenca del río Luján (Argentina). Ecología Austral 11(2): 79-85.

CAVAlieri, F. 1959. Una nueva especie de anfípodo de agua dulce. Physis 21: 278-288.

Cavaleri, F. 1968. Hyalella pampeana sp. nov., una nueva especie de anfípodo de agua dulce. Neotropica 14(45): 106-117.

Chevreux, E. 1904. Mission de Crequi-Monfort et Senegal de la Grange note premilinar sur les amphipods recueillis par M. le Dr. Neveu-Lemarie dans le Lac Titicaca (Julliet, 1903). Bulletin de la Societé Française de Zoologie 29: 131-134.

Chevreux, E. 1907. Les amphipods des Lacs des Hauts Plateux de l'Amerique du Sud. Misión Scientifique G. de CrequiMonfort et Senechal de la Grange, Lacs Hauts Plateaux de l'Amerique du Sud. 22 pp.

Coleman, O., \& GonzÁlez E.R., 2006. New hyalellids (Crustacea, Amphipoda, Hyalellidae) from Lake Titicaca. Organism, Diversity \& Evolution 6: 1-28.

Cunningham, R.O. 1871. XVII. Notes on the reptiles, amphibian, fishes, mollusca and crustacea obtained during the vollage of the H.M.S. "Nassau" in the years 1866-69. Transactions of the Linnean Society of London 27: 465-502.

Cussac, V., Ortubay, S., Iglesias G., Milano, D., Lattuca M.E., Barriga, J.P., Battini, M., \& Gross M. 2004. The distribution of South American galaxiid fishes: The role of biological traits and post-glacial history. Journal of Biogeography 31: 103-121.

Da Silva, D., \& Bond-Buckup, G. 2008. Pairing and reproductive success in two sympatric species of Hyalella (Crustacea, Amphipoda, Dogielinotidae) from southern Brazil. Acta Oecologica, 33: 49-55.

De Los Ríos-Escalante, P. 2011. A null model for the study of community structure of microcrustacean assemblages in northern Chilean shallow lakes. Crustaceana 84(5/6): 513521.

De Los Ríos, P., Adamowicz S., \& Witt, J. 2010. Aquatic fauna in the driest desert on earth: first report on the crustacean fauna of the Loa river (Atacama desert, Antofagasta region, Chile). Crustaceana 83(3): 257-266.

De Los Ríos, P., Hauenstein, E., Acevedo, P., \& Jaque, X. 2007. Littoral crustaceans in mountain lakes of Huerquehue National Park (38 S, Araucania region, Chile). Crustaceana 80(4): 401-410.

De Los Ríos, P., \& Roa, G. 2010. Species assemblages of zooplanktonic crustaceans in mountain shallow ponds of Chile (Parque Cañi). Zoologia-Curitiba 27(1): 81-86.
De Los Rios, P. \& Romero-Mieres, M. 2009. Littoral crustaceans in lakes of Conguillio National Park ( $\left.38^{\circ} \mathrm{S}\right)$, Araucania region, Chile. Crustaceana 82(1): 117-119.

Dos Santos, A., Araujo, P., \& Bond-Buckup, G. 2008. New species and new reports of Hyalella (Crustacea, Amphipoda, Dogielinotidae) from Argentina. Zootaxa 1760: 24-36.

Dutra B.K., Santos, R.B., Bueno, A.A.P., \& Oliveira, G.T. 2008. Seasonal variations in the biochemical composition and lipoperoxidation of Hyalella curvispina (Crustacea, Amphipoda). Comparative Biochemistry \& Physiology Part A. 151(3): 322-328.

FAXON, W. 1876. Exploration of lake Titicaca by Alexander Agazziz and S.W. Garman. IV. Crustacea. Bulletin of the Museum of Comparative Zoology 3: 361-375.

Galan, G \& HERRERA F.F. 2006. Fauna cavernícola de Venezuela: una revisión. Boletín de la Sociedad Venezolana de Espeleología 40: 39-57.

GonzÁlez, E. 2003. The freshwater amphipods Hyalella Smith, 1874 in Chile (Crustacea: Amphipoda). Revista Chilena de Historia Natural 76(4): 623-637.

GonzÁlez, E, Bond-Buckup, G., \& Araujo, P. 2006. Two new species of Hyalella from southern Brazil (Amphipoda: Hyalellidae) with a taxonomic key. Journal of Crustacean Biology 26(3): 355-365.

GonzÁlez, E. \& Coleman, C.H. 2002. Hyalella armata (Crustacea, Amphipoda, Hyalellidae) and the description of a related new species from Lake Titicaca. Organism Diversity and Evolution, Electronic Supplement 6: 1-19

GonzÁlez, E.R. \& Watling L. 2001. Three new species of Hyalella from Chile (Crustacea: Amphipoda: Hyalellidae). Hydrobiologia 464(1): 175-199.

GonzÁlez, E. \& Watling, L. 2002a. Redescription of Hyalella azteca from its type locality, Vera Cruz, Mexico (Amphipoda: Hyalellidae). Journal of Crustacean Biology 22(1): 173-183.

GonzÁlez, E. \& Watling, L. 2002b. A new species of Hyalella from the Andes in Perú (Crustacea: Amphipoda: Hyalellidae). Revista de Biología Tropical 50(2): 649-658.

GonzÁlez, E. \& WatLing, L. 2002c. Redescription of the freshwater amphipod Hyalella faxoni from Costa Rica (Crustacea: Amphipoda: Hyalellidae). Revista de Biología Tropical 50(2): 659-667

GonzÁlez, E. \& Watling, L. 2003a. A new species of Hyalella from the Patagonia, Chile, with redescription of $H$. simplex Schellenberg, 1943 (Crustacea: Amphipoda). Journal of Natural History 37(17): 2077-2094.

GonzÁlez, E. \& Watling, L. 2003b. A new species of Hyalella from Colombia, and the redescription of $H$. meinerti Stebbing, 1899 from Venezuela (Crustacea: Amphipoda). Journal of Natural History 37(17): 2095-2111.

GonzÁlez, E. \& Watling, L. 2003c. A new species of Hyalella from Brazil (Crustacea: Amphipoda: Hyalellidae), with redescriptions of three other species in the genus. Journal of Natural History 37(17): 2045-2076.

GonzÁlez, E. \& Watling, L. 2003d. Two new species of Hyalella from Lake Titicaca, and redescriptions of four others in the genus (Crustacea: Amphipoda). Hydrobiologia 497: 181-204.

Grosso, L. \& Peralta, M. 1999. Anfípodos de agua dulce sudamericanos. Revisión del género Hyalella Smith. I. Acta Zoológica Lilloana 45: 79-98. 
LopretTo, E.C. 1982. Contribución a la bioecología del anfípodo dulcecuícola Hyalella pampeana Cavalieri. II. Nota preliminar sobre el desarrollo embrionario. Neotropica 28: 97-112.

Lopretto, E.C. 1983a. Contribución a la bioecología del anfípodo dulceciacuícola Hyalella pampeana Cavalieri. I. Comportamiento reproductivo. Limnobios 2: 371-378.

Lopretto, E.C. 1983b. Contribución a la bioecología del anfípodo dulceciacuícola Hyalella pampeana Cavalieri. III. Desarrollo postembrionario. Limnobios 2: 471-490

Jergentz, S., Pessacq, P., Mugni, H., Bonetto, C., \& Schulz, R. 2004. Linking in situ bioassays and population dynamics of macroinvertebrates to assess agricultural contamination in streams of the Argentine pampa. Ecotoxicology and Environmental Safety 59(2): 133-141.

Menu-marque S., Morrone, J.J. \& Locascio De Mitrovich, C. 2000. Distributional paterns of the South American species of Boeckella (Copepoda: Centropagidae): A track analysis. Journal of Crustacean Biology 20(2): 262-272.

Miserendino, M.L. 2001. Macroinvertebrate assemblages in Andean Patagonian rivers and streams: Environmental relationships. Hydrobiologia 444(1): 147-158.

Miserendino, M.L., Brand, C., \& Di Prinzio. C.Y. 2008. Assessing urban impacts on water quality, benthic communities and fish in streams of the Andes Mountains, Patagonia (Argentina). Water Air Soil Pollution 194(1/4): 91-110.

Moreira, C. 1903. Uma especie nova de amphipode orechestichoideo, que vive a 2240 metros sobre el nível do mar. Archivos do Museu Nacional Rio do Janeiro 12: 187-190.

Morrone, J. J. 2001. An unjustified replacement name for Hyalella patagonica (Cunningham, 1871) (Crustacea: Amphipoda: Hyalellidae). Physis (Buenos Aires) secc. B, 58: 19.

Morrone, J. J. 2004. Panbiogeografía, componentes bióticos y zonas de transición. Revista Brasileira de Entomologia 48(2): 149-162.

Morrone, J. J. 2006. Biogeographic areas and transition zones of Latin America and the Caribbean Islands based on panbiogeographic and cladistic analyses of the entomofauna. Annual Review of Entomology 51: 467494.

Morrone, J. J. 2009. Evolutionary biogeography: An integrative approach with case studies. Columbia University Press, New York.

Pereira, V. F.G. 1985. Redescrição de Hyalella pernix (Moreira) (Amphipoda - Hyalellidae) com discussão de seu sinonimo H. curvispina Shoemaker. Revista Brasileira de Zoologia, São Paulo 3: 209-217.

PereirA, V.F.G. 1989. Uma nova espécie de anfípode cavernícola do Brasil Hyalella caeca sp.n. (Amphipoda, Hyalellidae). Revista Brasileira de Zoologia 6(1): 49-55

Pereira, V.F.G. 2004. Hyalella dielaiii sp. nov. from São Paulo, Brazil (Amphipoda: Hyalellidae). Revista Brasileira de Zoologia 21(2): 179-184.

Pérez-Lozada M., Bond-Buckup, G., Jara, C.G., \& Crandall, K.A. 2002. Phylogenetic relationships among the species of Aegla (Anomura: Aeglidae) freshwater crabs from Chile. Journal of Crustacean Biology 22(2): 304-313.

Pérez-Lozada M., Bond-Buckup, G., Jara, C.G., \& Crandall, K.A. 2004. Molecular systematic and biogeography of the southern South American freshwater "crabs" Aegla
(Decapoda: Anomura: Aeglidae) using multiple heuristic tree search approaches. Systematic Biology 53(5): 767780.

Pérez-Lozada M., Bond-Buckup, G., Jara, C.G., \& Crandall, K.A. 2009. Conservation assessment of southern South American freshwater ecoregion on the basis of the distribution and genetic diversity of crabs from the genus Aegla. Conservation Biology 23(3): 692-702.

Pugh, P.J.A., Dartnall H.J.G., \& Mcinnes, S.J. 2002. The non marine Crustacea of Antarctica and the Islands of the Southern Ocean: Biodiversity and Biogeography. Journal of Natural History 36(9): 1047-1103.

Rauque, C.A., \& Semenas, L. 2009. Effects of two acanthocephalan species on the reproduction of Hyalella patagonica (Amphipoda, Hyalellidae) in an Andean Patagonian lake (Argentina). Journal of Invertebrate Pathology 100(1): 3539.

Schellenberg, A., 1931. Gammariden and Caprelliden des Magellangebeites, Südgeorgiens und der Westantarktis. Further Zoological Results of the Swedish Antarctic Expedition 1901-1903, 2: 1-290.

SchoemaKer, C.R. 1942. A new species of Amphipoda from Uruguay and Brazil. Journal of the Washington Academy of Sciences 2: 637-661.

SмiтH, S.I. 1875. Report on Amphipod Crustaceans. Annual report of the United States Geological and Geographical Survey of the territories, Embracing Colorado. The explorarion for the year 1873, by F.V. Hayden, Washington, Government Printing Office 1874: 608-611.

Spaccessi, F., \& Rodríguez, A. 2009. Benthic invertebrate assemblage in Samborombón River (Argentina, S. America), a brackish plain river. Aquatic Ecology 43(4): 1011-1022.

Stebing, T.R.R. 1899. Amphipoda from the Copenhagen Museum und other sources, part II. Transactions of the Linnean Society, London (2, Zoology) 8: 1103-1111.

Stock, J.H. \& Plavoet, D. 1991. The freshwater Amphipoda of the Falkland islands. Journal of Natural History 25(6): 14691491.

VäınÖlä R, Witt, J.D.S., Grabowski, M., Bradbury, J.H., JADZEWSKI, K., \& SKet, B. 2008. Global diversity of amphipods (Amphipoda; Crustacea) in fresh water. Hydrobiologia 595: 241-255.

Witt, J.D.S., Blinn, D.W., \& Hebert, P.D.N. 2003. The recent evolutionary origin of the phenotypically novel amphipod Hyalella Montezuma offers an ecological explanation for morphological statis in a closely allied stasis in a closely allied species complex. Molecular Ecology 12(2): 405413.

Witt, J.D.S., \& Hebert, P.D.N. 2000. Cryptic species diversity and evolution in the amphipod genus Hyalella within central glaciated North America: A molecular phylogenetic approach. Canadian Journal of Fisheries and Aquatic Sciences 57(4): 687-698.

WrzesniowsKi, A. 1879. Vorlaufige Mitteilungen über einige Amphipoden. Zoologisher Anzeiger 2: 18-45.

Zilli, F.L., Montalto, F. \& Marchese, M.r. 2008. Benthic invertebrate assemblages and functional feeding groups in the Paraná River floodplain (Argentina). Limnologica 38(2): 159-171. 


\section{APPENDIX}

H. anophthalma (Ruffo, 1957). Venezuela: Cuevas de Hueque (Galán \& Herrera, 2006).

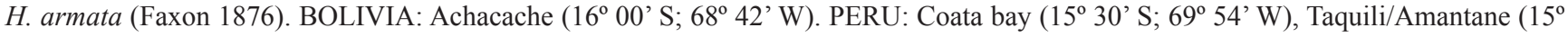

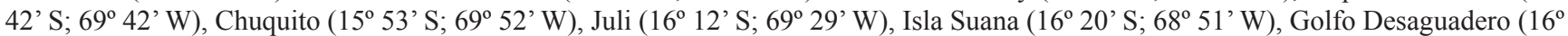
$33^{\prime}$ S; $69^{\circ} 02^{\prime}$ W) (González \& Coleman 2002).

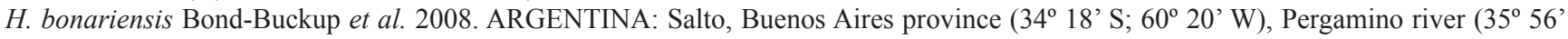

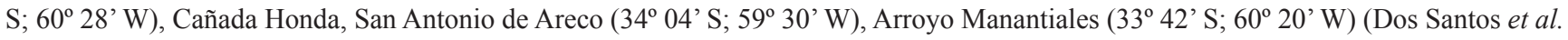
2008).

H. brasiliensis Bousfield 1996. BRAZIL: stream close to Prudentopolis (25 12' S; 50 57’ W).

H. caeca Pereira \& Goulart 1989. BRAZIL: Gruta Tobias de Baixo, Município de Ipiranga (around 23² 26’ S; 47²5’ W) (Pereira 1989).

Hyalella carstica (Bastos-Pereira \& Bueno, 2012). BRAZIL: High Sao Francisco River (20¹9'59,6' S; 45³6’25.3”'W) (Bastos-Pereira \& Bueno, 2012).

H. castroi González et al. 2006. BRAZIL: Vale das Trutas (28 47' S; 49 51' W) (González et al. 2006).

H. chiloensis González \& Watling 2001. CHILE: Notuco, Chiloé (42 39’ S; 73 49’ W), Laguna Redonda, Concepción (36 48' S; $73^{\circ}$ 04'W), río Ñirepan, Coihaique (around 453' S; 72 03' W) (González 2003).

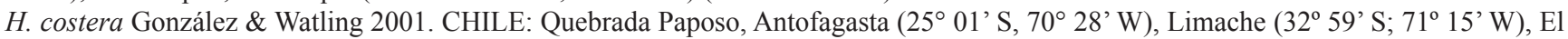

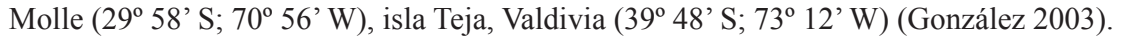

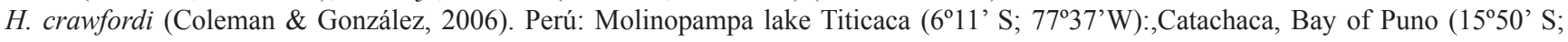
$71^{\circ} 08^{\prime}$ W) (Coleman \& González, 2006).

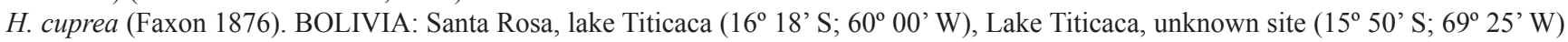
(González \& Watling 2003d).

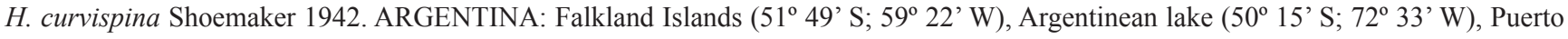

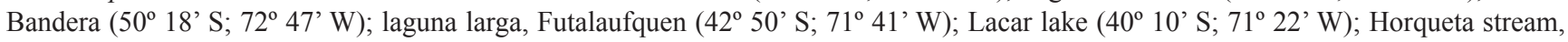

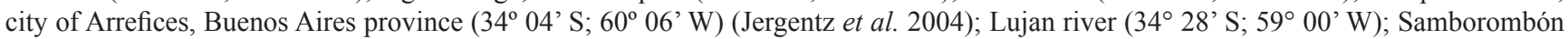

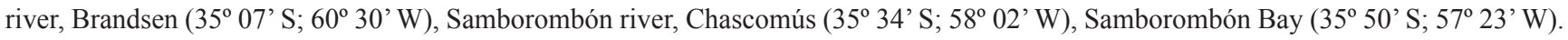

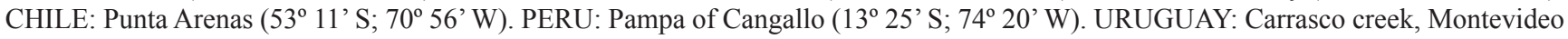
(around 34 53' S; 56 03' W) (Grosso \& Peralta 1999; Casset et al. 2001; Dos Santos et al. 2008; Dutra et al. 2008; Spaccesi \& Rodrígues 2009).

H. dielaiii Pereira 2004. BRAZIL: Alto da Serra, São Paulo (around $27^{\circ} 01^{\prime}$ S; 52 $47^{\circ}$ W) (Pereira 2004).

H. dybowskii (Wrzesniowski 1879). PERU: Paucal, Montaña Nacho (07º 00' S; $79^{\circ} 08^{\prime}$ W) (González \& Watling 2002b).

H. echinus (Coleman \& González, 2006). PERU: Siripata, Uruñi bay, lake Titicaca (1550' S; $71^{\circ} 08^{\prime}$ W)

(Coleman \& González, 2006).

H. falklandensis Bousfield 1996. ARGENTINA: West Falkland, 4 sites (around 51 ${ }^{\circ} 39^{\prime} \mathrm{S} ; 59^{\circ} 58^{\prime} \mathrm{W}$ ); East Falkland, 4 sites (around $51^{\circ}$ 49’ S; 58 52’ W) (Stock \& Plavoet 1991; Dos Santos et al. 2008).

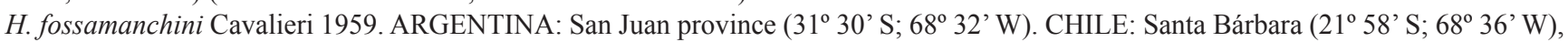

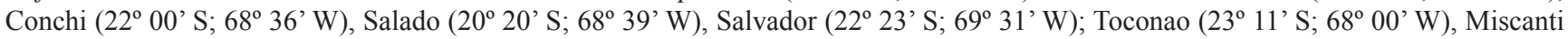

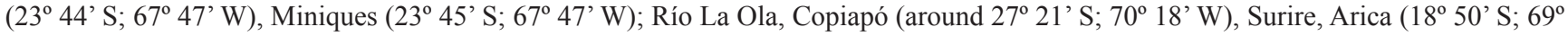

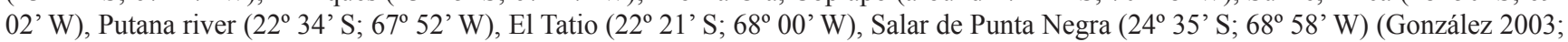
Dos Santos et al. 2008; De los Ríos et al. 2010; De los Ríos-Escalante 2011).

H. franciscae González \& Watling 2003. CHILE: Laguna El Paso, Torres del Paine (50²9’ S; 72 58' W), Lago Risopatrón (44 $15^{\prime}$ ' S;

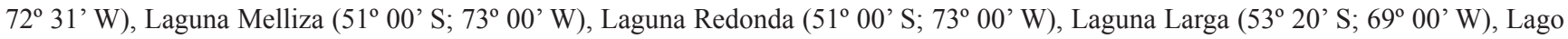

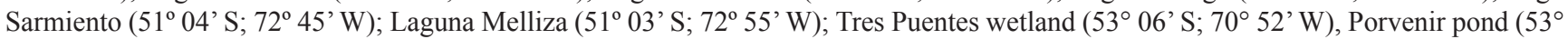
17’ S; 70 19’ W) (González 2003; González \& Watling 2003a).

Hyalella gauthieri (Coleman \& González, 2006). Perú: Oruñi Bay, Taquili island (1546’ S; 6941' S) (Coleman \& González, 2006).

H. gracilicornis (Faxon 1876). BRAZIL: Campos, Rio de Janeiro (21 $28^{\prime}$ S; $\left.41^{\circ} 13^{\prime} \mathrm{W}\right)$, Represa Belvedere, Campus da UFV, Minas Gerais State (18 $55^{\prime}$ S; $48^{\circ} 01^{\prime}$ W) (González \& Watling 2003c).

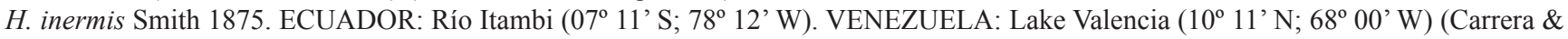
Gunkel 2003; González \& Watling 2003b).

H. jelskii (Wrzesniowski 1879). PERU: Cordillera de Punamarca (14º 02' S; 76 16’ W) (González \& Watling 2002 b).

H. kochi González \& Watling 2001. ARGENTINA: Jujuy province, Yavi Chico River $\left(22^{\circ} 05^{\prime}\right.$ S; $65^{\circ} 25^{\prime}$ W), reservoir near Escuela Agrotécnica in Huamahuaca ( $23^{\circ} 11^{\prime} \mathrm{S}$; $\left.65^{\circ} 20^{\prime} \mathrm{W}\right)$, Tilcara, lake north of Tilcara, near Río Grande $\left(23^{\circ} 33^{\prime} \mathrm{S} ; 65^{\circ} 23^{\prime}\right.$ W), Tucumán

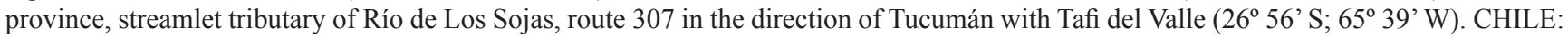

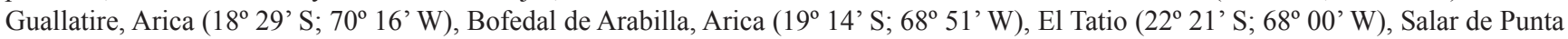

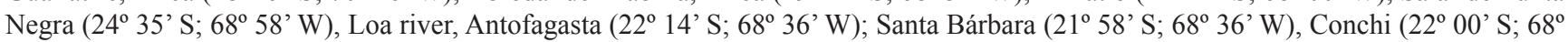

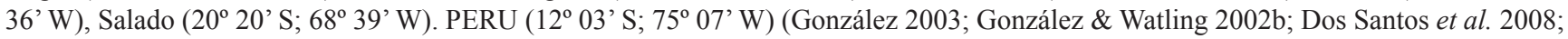
De los Ríos et al. 2010).

H. latimanus (Faxon 1876). BOLIVIA: Llampopata, lake Titicaca ( $\left.16^{\circ} 00^{\prime} \mathrm{S} ; 6^{\circ} 15^{\prime} \mathrm{W}\right)$, Isla Coati, lake Titicaca (16 $\left.15^{\circ} \mathrm{S} ; 6^{\circ} 40^{\prime} \mathrm{W}\right)$, Huatajata, lake Titicaca $\left(16^{\circ} 15^{\prime} \mathrm{S} ; 68^{\circ} 45^{\prime} \mathrm{W}\right)$ (González \& Watling 2003d).

H. longipalma (Faxon 1876). BOLIVIA: lake Titicaca (16 ${ }^{\circ} 25^{\prime}$ S; $68^{\circ} 45^{\prime}$ W) (González \& Watling 2003d). 
H. longipes (Faxon 1876). BOLIVIA: Achacache, lake Titicacaca (16º 06' S; 68 26’ W) (González \& Watling 2003d).

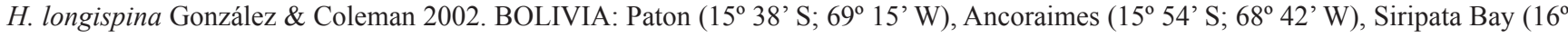

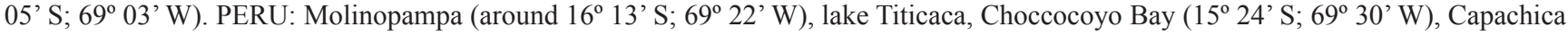

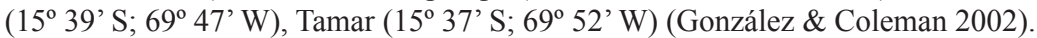

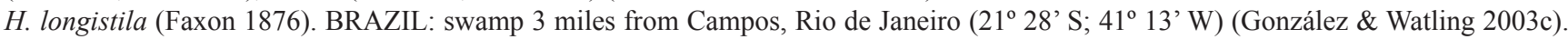

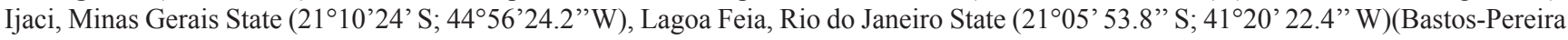
\& Bueno, 2012).

H. lubomirskii (Wrzesniowski 1879). PERU: Pacasmayo (07² 25' S; 79³ 34' W) (González \& Watling 2002b).

H. lucifugax (Faxon 1876). BOLIVIA: Juli, lake Titicaca (16º 10' S; 69³ 30' W) (González \& Watling 2003d).

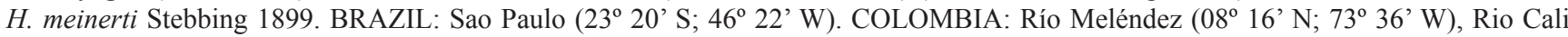

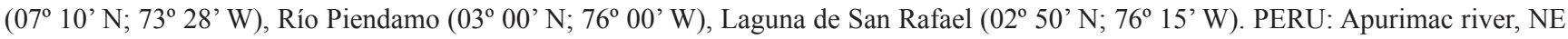

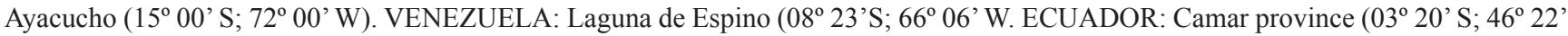
W) (González \& Watling 2002b, 2003b).

H. montenegrinae Bond-Buckup \& Araujo 1998. BRAZIL: Rio Grande do Sul, municipio de Sao José dos Ausentes (29²9’ S; 50 15’ W) (Bond-Buckup \& Araujo 1998).

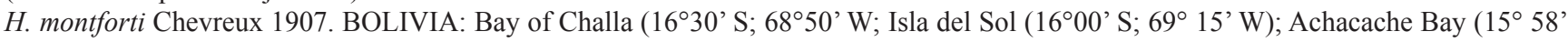

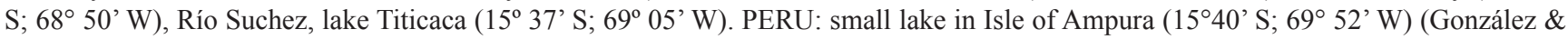
Watling 2003d).

H. nefrens González \& Watling 2003. BOLIVIA: Santa Rosa, lake Titicaca (16º 18 ' S; 60 00’ W) (González \& Watling 2003d).

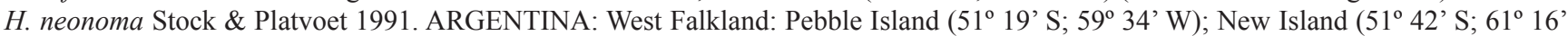

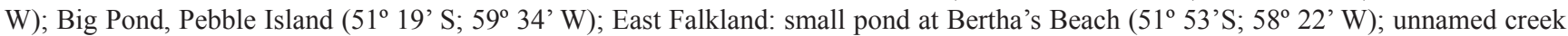

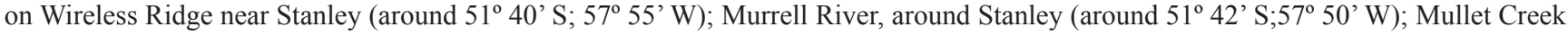

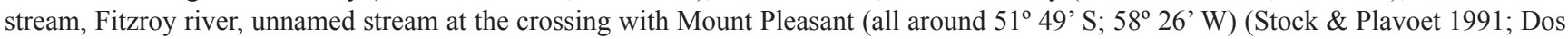
Santos et al. 2008).

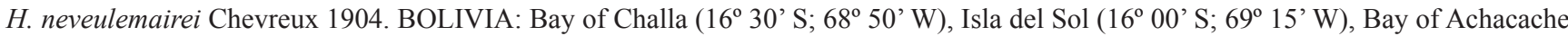

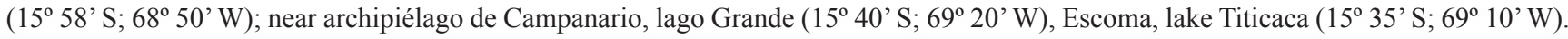

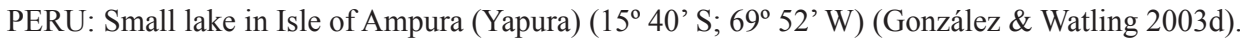

H. pampeana Cavalieri 1968. ARGENTINA: Arroyo Vitel, Chascomús lagoon (35³3' S; 58 03’ W); Laguna de Cardiel (Lopretto 1983a; Dos Santos et al. 2008).

H. patagonica (Cunningham 1871) (= H. araucana Grosso \& Peralta 1999, see Morrone 2001). ARGENTINA: Peninsula near Ushuaia,

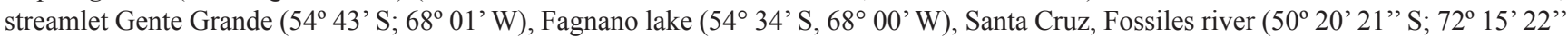

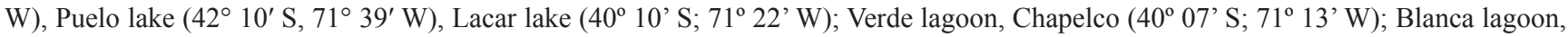

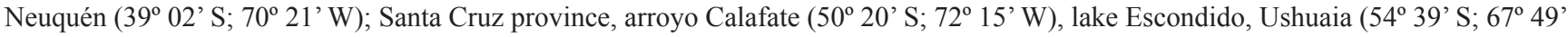

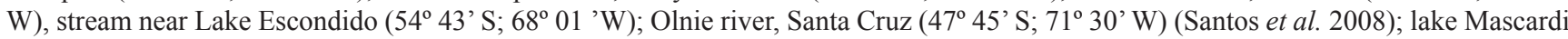

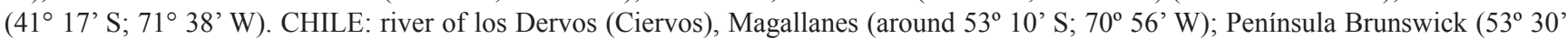

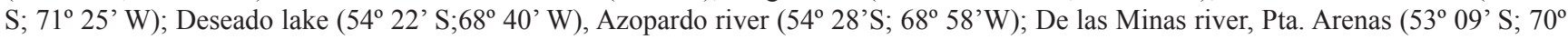

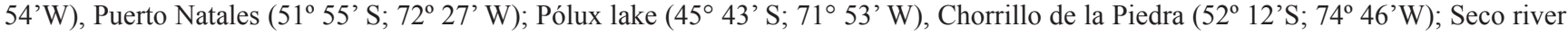

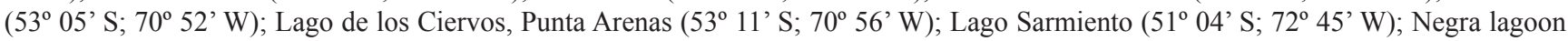

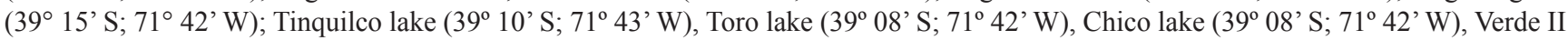

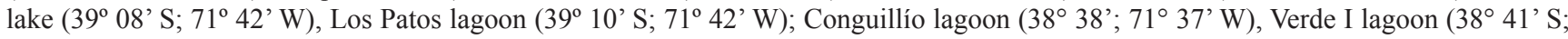

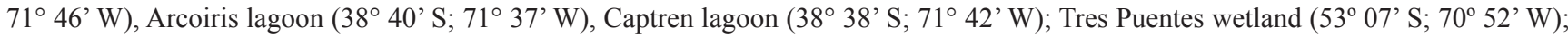

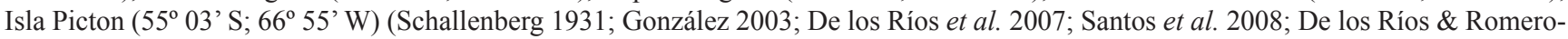
Mieres 2009; Rauque \& Semenas 2009; De los Ríos \& Roa, 2010).

H. paramoensis Andres 1988. COLOMBIA: Laguna Negra, Paramo de Chisaca (04² 20’ N; 74 12’ W) (González \& Watling 2003b).

H. pauperocavae González \& Watling 2002. PERU: trout culture station “El Ingenio", Huancayo (1203' S; 7507' W) (González \& Watling 2002b).

H. pernix (Moreira 1903). BRAZIL: Lagoa Esgotada, Itatiaia, Rio de Janeiro (around 22 30' S; 44 37' W) (Pereira 1985).

H. pleoacuta González et al. 2006. BRAZIL: Rio Grande Do Sul, Sao José Dos Ausentes, Vale das Trutas (28 47’ S; 4950’ W) (González et al. 2006; Da Silva \& Bond-Buckup 2008).

H. pseudoazteca González \& Watling 2003. BRAZIL: Reserva Ecológica de Taim, Rio Grande do Sul State (32 $27^{\circ}$ S; 52 $38^{\prime}$ W) (González \& Watling 2003c).

H. quindioensis González \& Watling 2003. COLOMBIA: Quindio (06 14' N; 73² 26’ W) (González \& Watling 2003b).

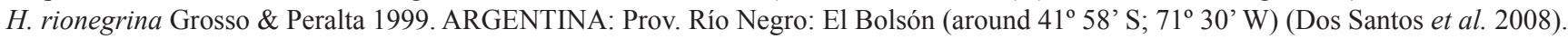
H. robusta Chevreux 1907. BOLIVIA: Bay of Achacache (1606' S; 68 26’ W) (González \& Watling 2003d).

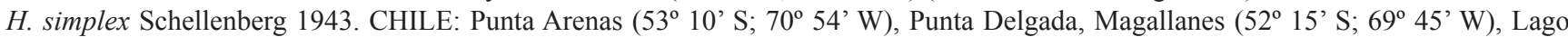

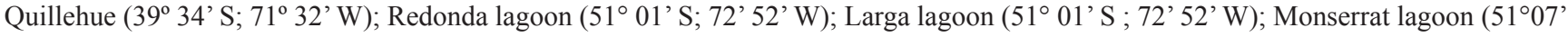

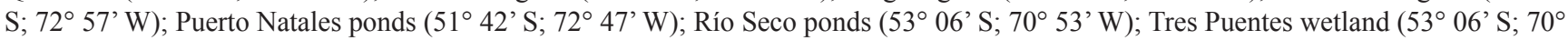

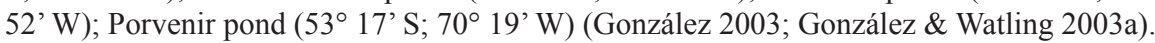

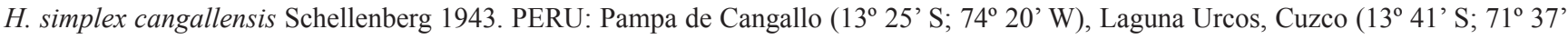
W) (González \& Watling 2002b). 
Hyalella en Sudamerica: De los Ríos-Escalante, P. ET AL.

H. solida (Chevreux 1907). PERU: Small lake in isle of Ampura (Yapura) (15²0' S; 69 52' W) (González \& Watling $2003 \mathrm{~d}$ ).

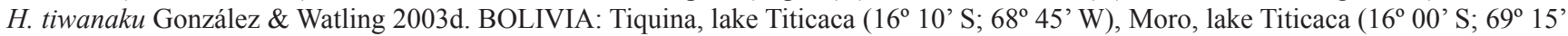

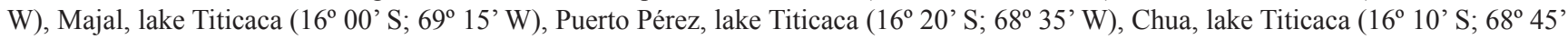
W), Lago Mullini (170 $04^{\prime}$ S; 66 37’ W) (González \& Watling 2003d).

H. warmingi (Stebbing 1899). BRAZIL: Lagoa Santa, Minas Gerais State (19³ $\left.38^{\prime} \mathrm{S} ; 43^{\circ} 53^{\prime} \mathrm{W}\right)$, Gruta Mirasol, Sao Paulo State (20 00' S; 4900’ W) (González \& Watling 2003c).

Recibido: 15.12.11

Aceptado: 13.08.12 